IRA-International Journal of Management \& Social Sciences

ISSN 2455-2267; Vol.06, Issue 03 (2017)

Pg. no. 509-517

Institute of Research Advances

https://research-advances.org/index.php/RAJMSS

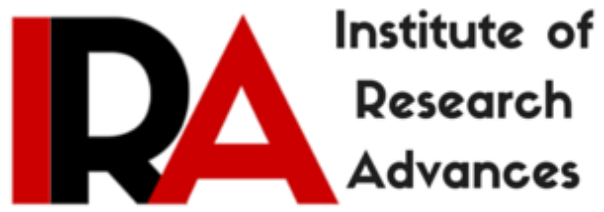

\title{
Role of Banks in Ensuring a Sustainable and Inclusive Growth
}

\section{Saurabh Agarwal}

Research Scholar, Department of EAFM, University of Rajasthan, Rajasthan, India.

Type of Review: Peer Reviewed.

DOI: http://dx.doi.org/10.21013/jmss.v6.n3.p16

\section{How to cite this paper:}

Agarwal, S. (2017). Role of Banks in Ensuring a Sustainable and Inclusive Growth. IRAInternational Journal of Management \& Social Sciences (ISSN 2455-2267), 6(3), 509-517. doi:http://dx.doi.org/10.21013/jmss.v6.n3.p16

(C) Institute of Research Advances

(cc) EY-NC

This work is licensed under a Creative Commons Attribution-Non Commercial 4.0 International License subject to proper citation to the publication source of the work.

Disclaimer: The scholarly papers as reviewed and published by the Institute of Research Advances (IRA) are the views and opinions of their respective authors and are not the views or opinions of the IRA. The IRA disclaims of any harm or loss caused due to the published content to any party. 


\begin{abstract}
Economic growth in India has to be inclusive in order to make it sustainable. Inclusiveness is an essential element in a democracy. If policies that bring about economic growth do not benefit the people in a wide and inclusive manner, they will not be sustainable. Equally, inclusive growth is essential to grow the market size, which alone will sustain growth momentum. Inclusive growth is the only just and equitable way that any society can grow. Financial Inclusion rests on three pillars viz. access to financial services, affordability of such services and actual utilization of such services. Financial Inclusion can be achieved only if all the three pillars show affirmative results. It may prove to be very useful for the banking Industry and the overall Indian economy. It will be useful for policy makers, academicians and researchers in the field.
\end{abstract}

Keywords: Sustainable, Inclusive, Financial, Rural, Urban, Growth, Demographic, Opportunities.

\title{
Introduction
}

In recent years, Indian economy has recorded a robust GDP growth. It has been growing nearly around 8\% CAGR in the last three years. But the benefits of economic growth have not equitably reached different parts of our society. The rural and agricultural sector, in particular, has not gained the desired momentum of growth and development. Further, within cities, the inequality is on the rise and demographic pressure is leading to growth of slums.

Present Government and the RBI have been promoting the necessity of inclusive banking, and the banking sector, as a collective body, and has taken several initiatives in this regard and till date a large number of farmer households have no access to formal sources of credit.

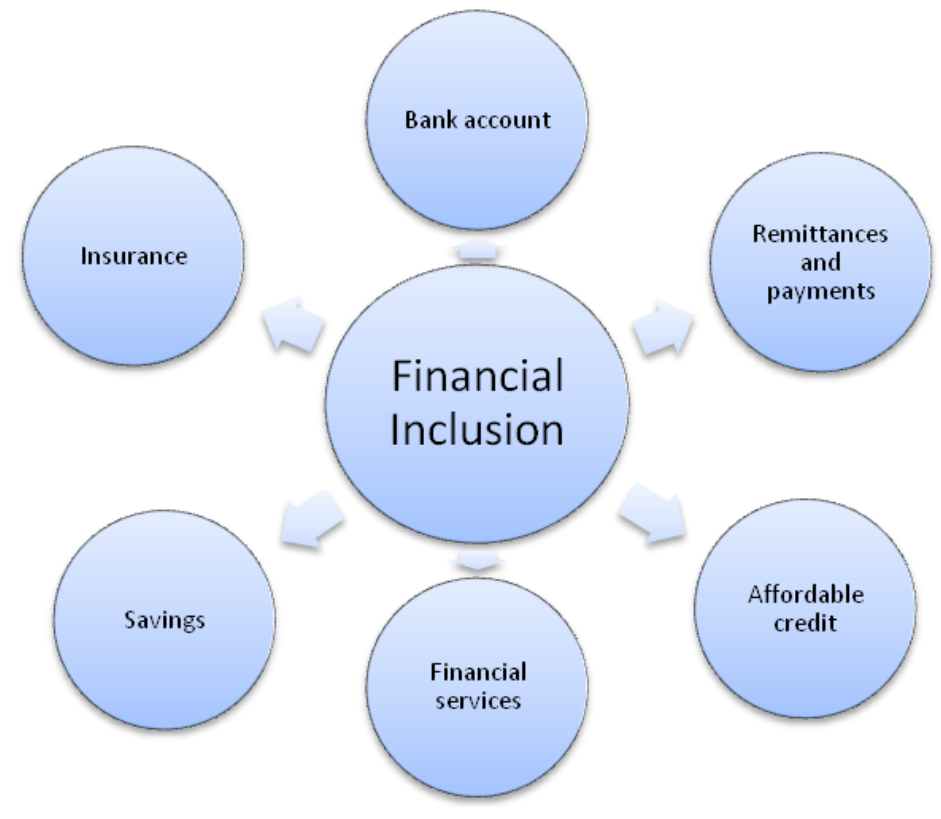

\section{Present Dynamics, Challenges and Opportunities}

Though banks have made significant strides in all areas of their performance, vast segments of population, particularly the underprivileged, are yet to be brought on to the canvas of banking services. It 
is in this context that all efforts are required to bring about financial inclusion and bring those segments of population into the mainstream of life. This would not only enable the banks to expand their market share but expand the overall market, in the process of tapping the Bottom of Pyramid (BoP) i.e. the customers from the lower income segments.

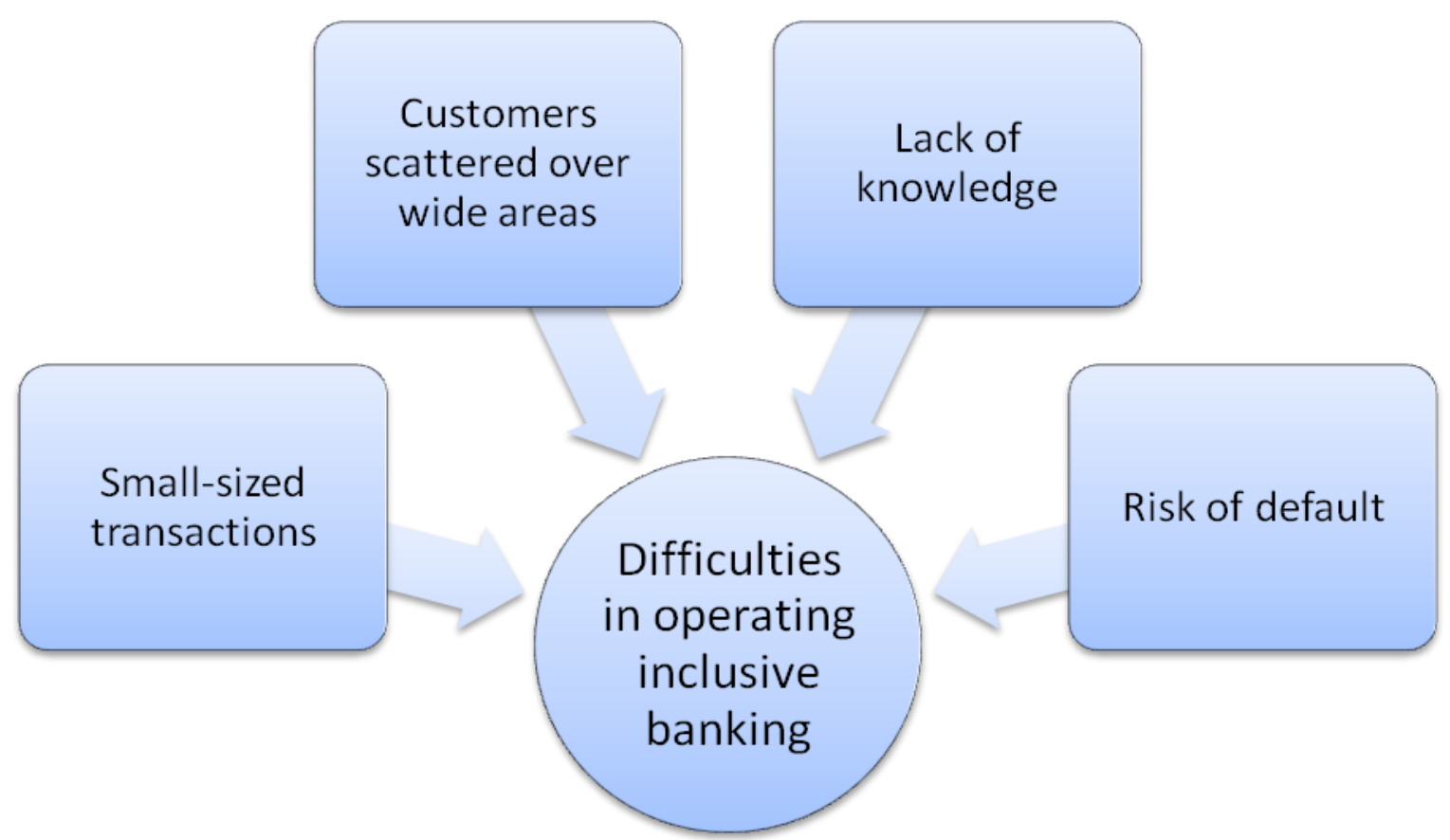

Figure: Difficulties in operating Inclusive banking

\section{Urban Population}

We have tried to divide the urban population into two parts for analyzing the financial inclusion perspective.

a.) The first category will be the stable low income group having an asset or a fixed business which will include people like auto rickshaw drivers, small repair shops, small tea-coffee point owners etc. It is important to bring these people under the umbrella of no-frills account. Though the no frills accounts are turning out to be a viable business opportunity for the banks its marketing has still not properly caught up. It is important for people to be aware about such accounts which does not require much documentation and can be opened with a minimum balance.

b.) The Know your customers (KYC) norms should be further simplified to enhance the reach of the scheme. Credit or loan facilities can be enhanced to the customers on the basis of the track record. Biometric or colour coded ATMs can be opened with reduced minimum withdrawal amounts to ease banking for the target customers for the no frills accounts. 


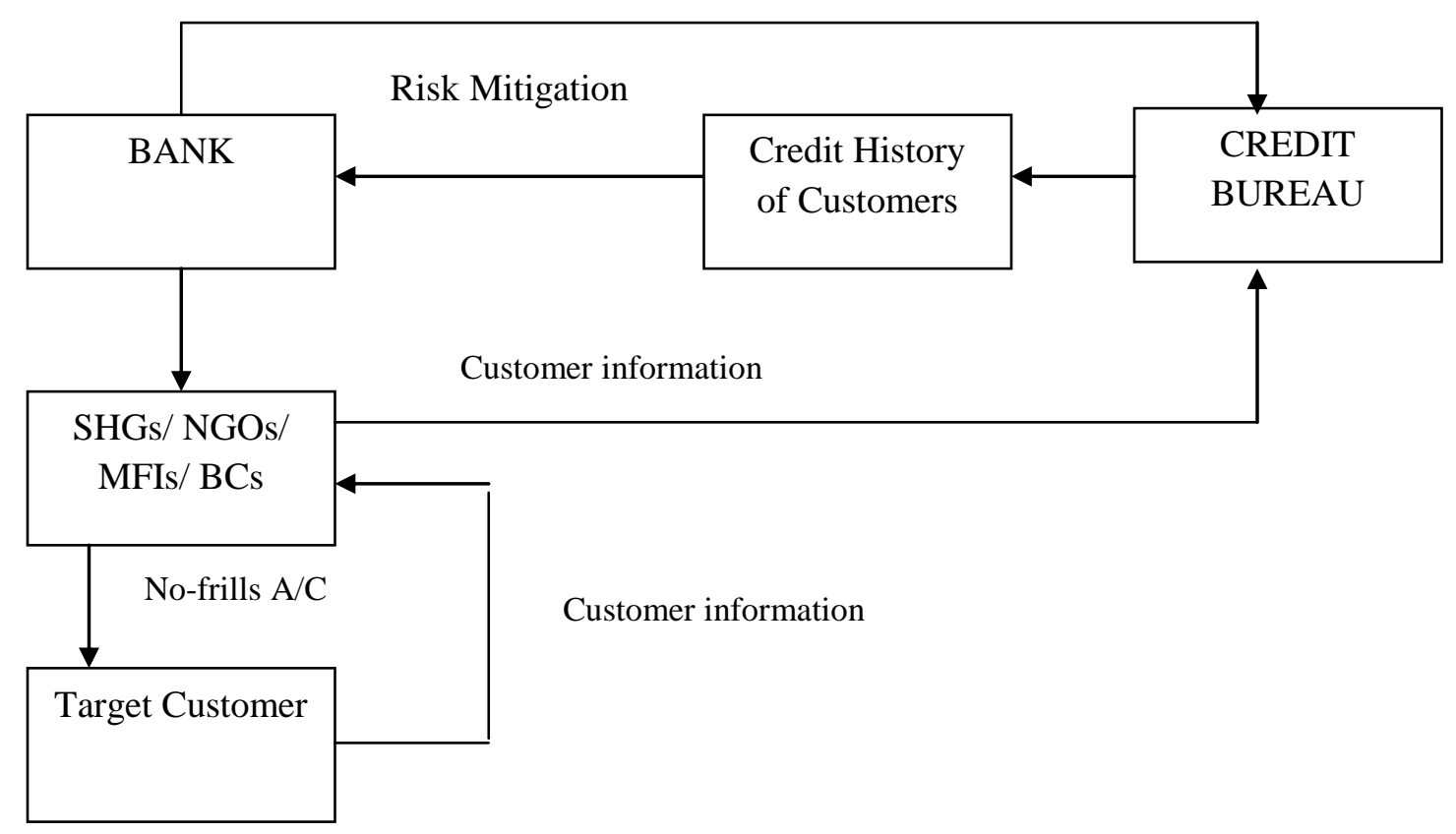

Figure: Model for Urban poor with steady income

c). The second kind of target customers will be the urban population who do not have a uniform flow of cash like the labour class of migratory nature. This is a predominantly a very low income group and they are not in a position to get a referral for a bank account and hence are unable to avail the banking facilities. The concept of micro -financing is difficult to extend to such people as it is difficult to form a group among such people as they frequently migrate from one place to another as and when the work on a site/ project gets completed. In addition it is a group usually male dominated so women cannot be included. This class presents a huge opportunity for the Indian banking industry. We have tried to develop a model which can be used to extend banking facilities to such people and also reduce the default risk. We need to understand the fact that bank loan is required by these people mostly for their families living in the village. The bank can open no- frills saving accounts for such people with initially the Aadhaar Card acting as the ID proof. After a very small minimum saving in the account, banks can extend loans to such people based on the total saving account. The bank will issue the labourer a "loan paper" and not the cash. This loan paper can be exchanged for cash at the post office of the taluka/ village the person belongs to. In this case the postman will act as a verifying agent for the information given by the person to whom the loan is extended. 


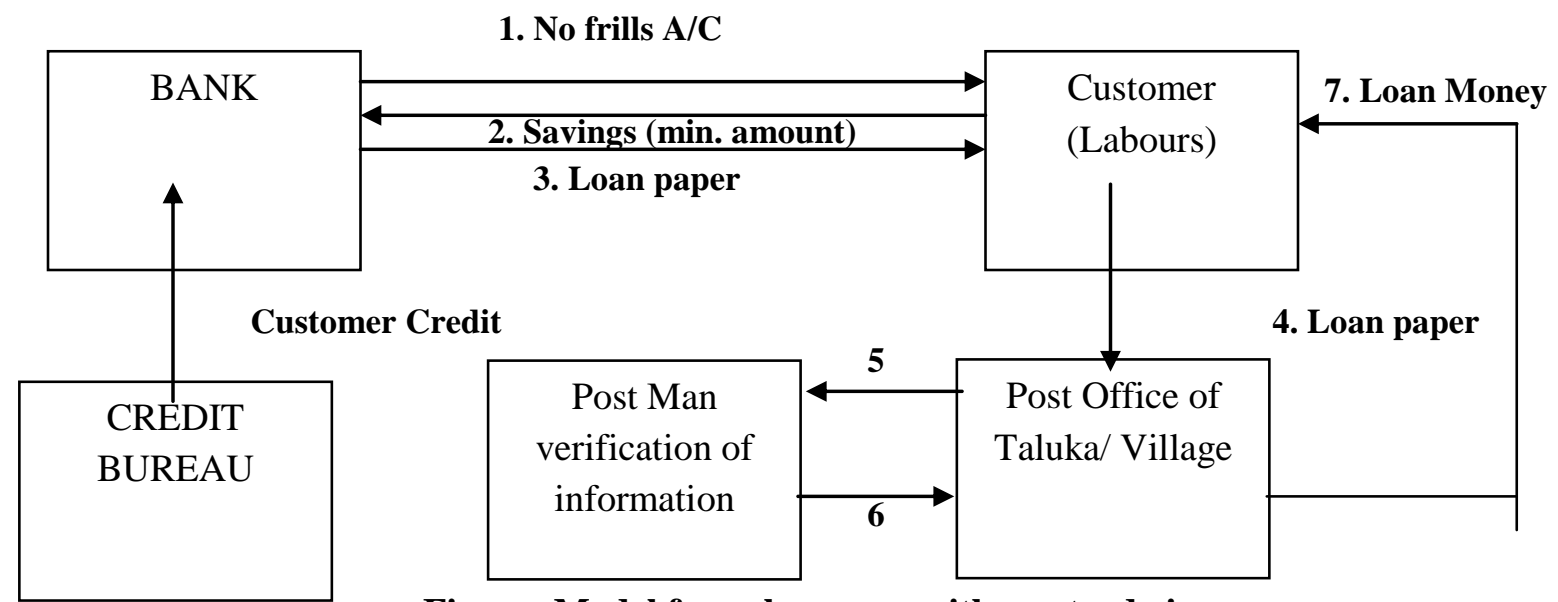

Figure: Model for urban poor with no steady income

\section{Rural Banking- Mobile banking Kiosks}

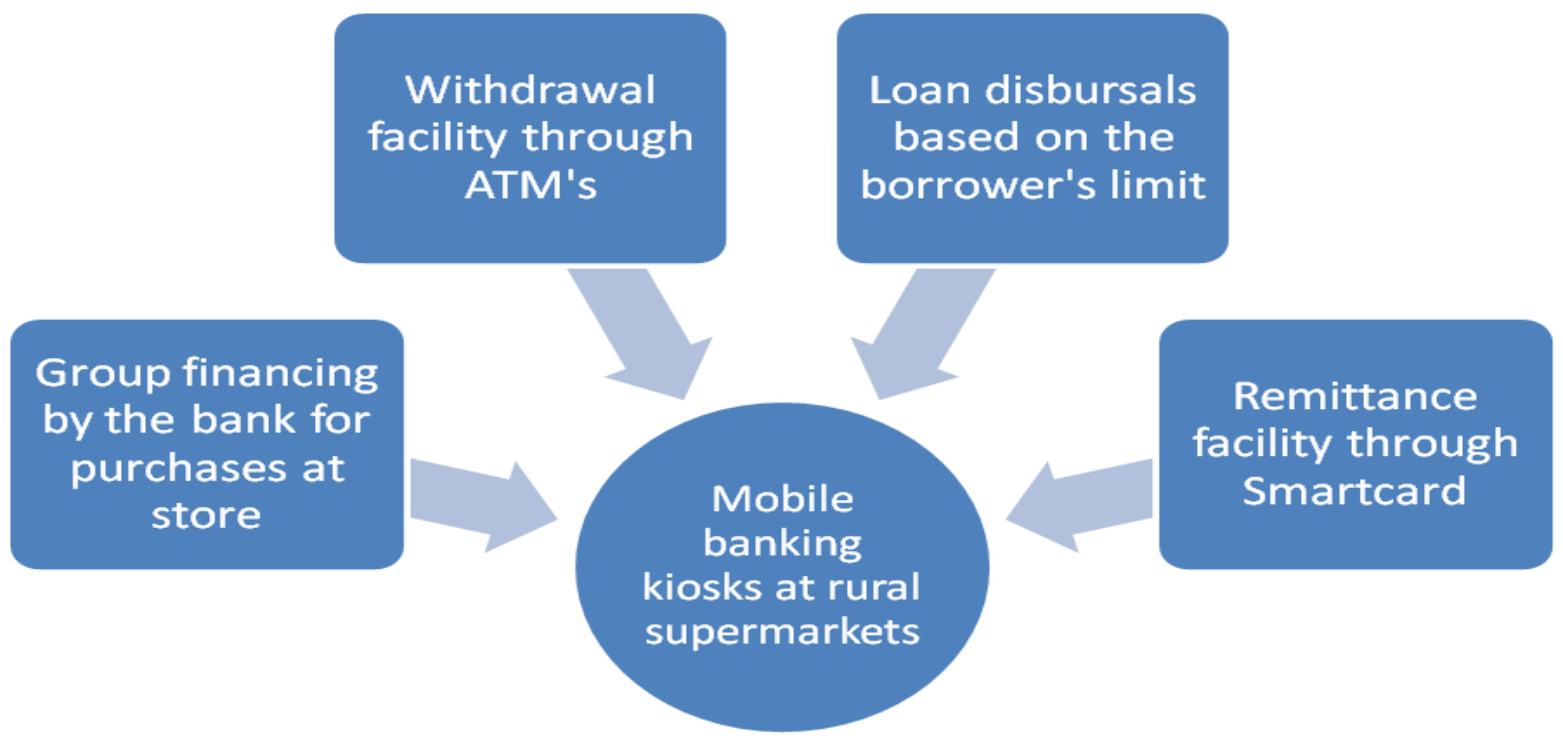

The rural supermarkets like ITC's Choupal sagar and Hariyali Kissan bazaar present an opportunity to provide banking services to the rural population especially farmers.

The bank can partly finance the purchases made at the store and facilitate repayments through EMI's etc. This is essential as the rural people do not have ready cash always, but might prefer to purchase on impulse. For expensive items the bank can finance a group of people rather than an individual to ensure recovery of the loan.

Withdrawal facilities through biometric ATM's in vernacular languages can also be provided at theses kiosks. The ATM's can enable withdrawal in small denominations which is preferred by the rural customers. The bank can also keep transaction costs at a minimum to encourage use of these. 
A large part of the rural population has migrated to urban areas. The bank can also facilitate remittances electronically using the mobile network from these people to their families in the villages who can withdraw money through ATM's. The account can also be viewed on a dynamic basis at the kiosk or on the mobile phone.

In addition to financing purchases loan disbursals can also be made by the mobile banking kiosk based on the past credit history of the borrower and the account balance. The bank can initially offer loans equivalent to 2-3 times the account balance and this exposure can be increased as the borrower makes regular payments and the account balance increases.

\section{Rural Banking: Agriculture Lending Model}

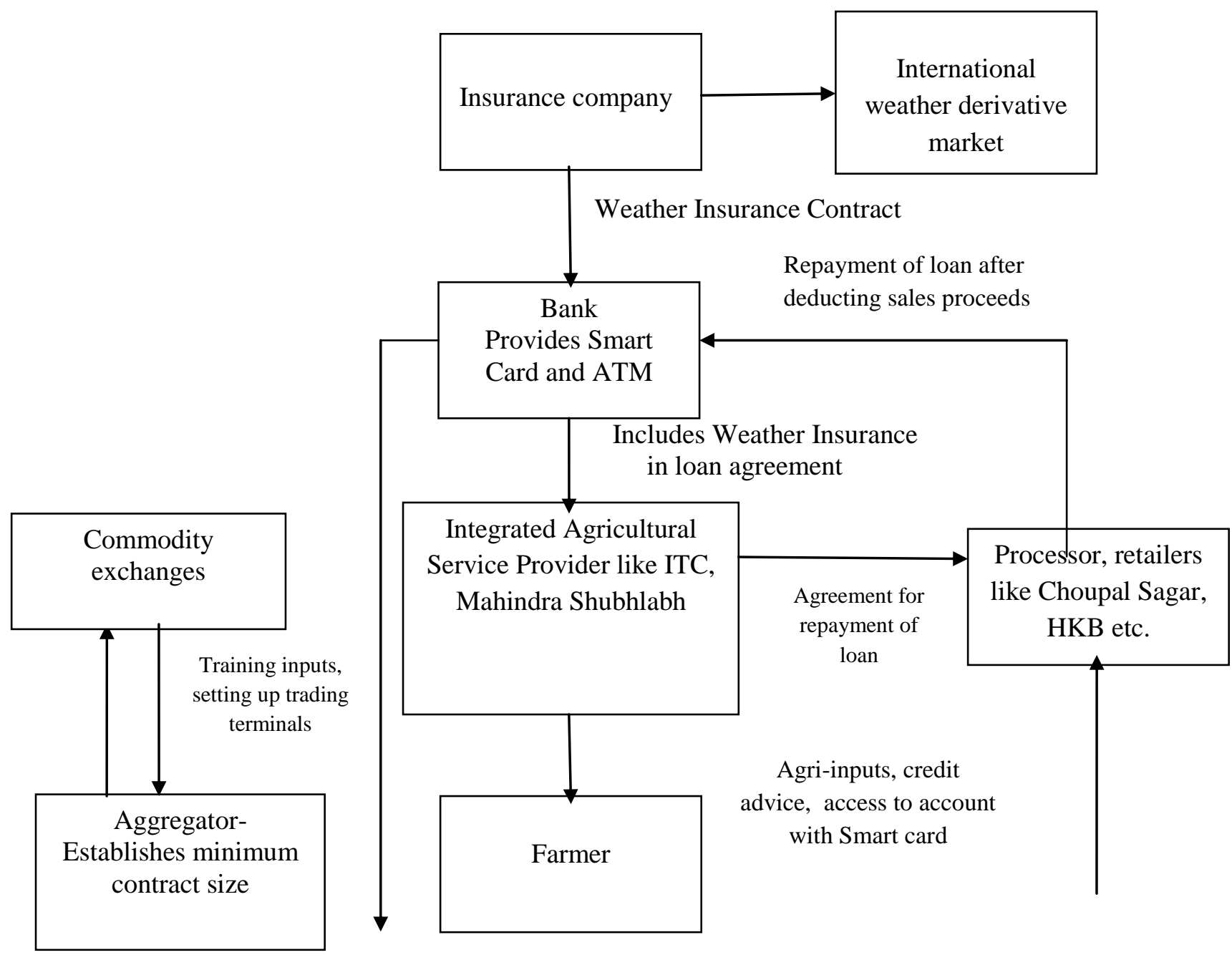

Figure: Rural Banking: Agriculture Lending Model 
The proposed model consists of the following components

\section{Insurance company}

The bank can tie up with an insurance company which reinsures most of the risk in national and international weather risk markets. Providers like ACE, SocGen, Swiss RE, Deutsche Bank are all in the weather risk business and would be willing to provide these facilities in India.

\section{Insurance-premium and savings account}

The farmer can pay the insurance premium in this account and can also use the proceeds when the weather index insurance does not adequately compensate losses, thereby mitigating the risk. In addition the farmer could be allowed to deposit cash into the account at specialized low-cost rural branches of the lending bank. They can be given credit according to the amount deposited in the account.

- In a normal year the farmer accumulates savings.

- In a mild drought year, the farmer receives interest relief from the weather insurance.

- If the weather insurance payout is not triggered, the farmer can dip into his savings account to meet his interest payments.

- In a severe drought year the farmer does not pay interest and pays only a part of the principal. In addition, he or she can use accumulated savings funds for further principal payment relief.

\section{Smart card}

The farmer can access his account through a Smart Card. Initially the card serves as a debit card in agricultural service center hubs, certain points of sale, and at ATMs and can later be upgraded to a credit card. The card may used to purchase agri-inputs like fertilizers, seeds and other items from rural supermarkets.

The model works as follows:

- The bank can identify an IASP like Mahindra Shubhlabh or ITC that has a good relationship with the farmer and provides agricultural inputs and crop-related information.

- Based on the recommendation of the IASP, bank provides credit like crop-loan, pre and post-harvest finance to the identified farmers and grants access to an account through Smartcard and ATM.

- Simultaneously, the bank can also tie-up with traders, processors or retail outlets which buy the produce from farmers. Loan processing, disbursement and collection are effectively done by the IASP.

- At the end of the season, the farmers supply the crop to the output buyer and the output buyer deducts the loan amount from the sale proceeds and remits the loan to ICICI Bank in full settlement of the loan amount. The IASP receives a service fee for the loan processing and supervision services. 


\section{Rural Model (The BANK-NGO-SHG model)}

1. Provides credit

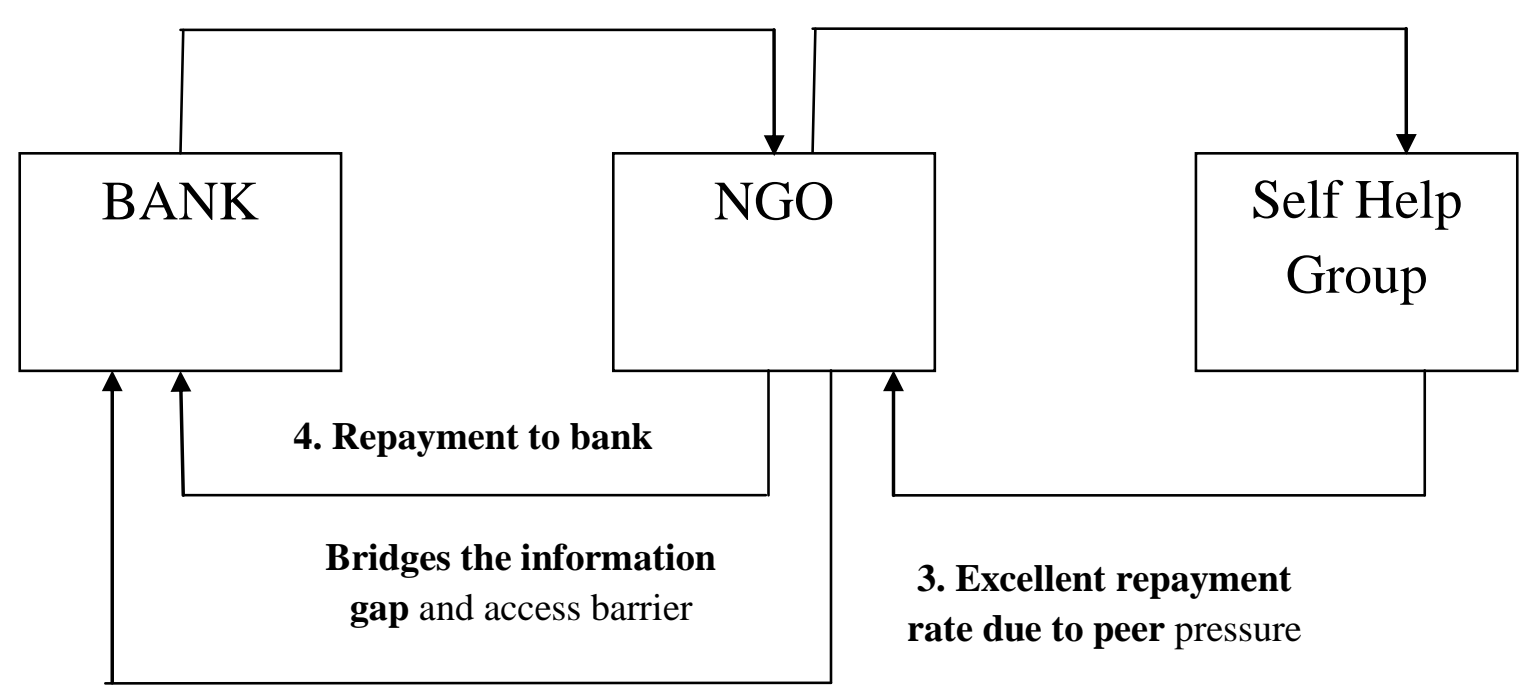

Figure: Bank-NGO-SHG Model

In Bank-NGO-SHG model for Rural India, Bank would tie up with local NGOs to act as facilitator between the bank and the SHG that wants to initiate micro savings through a savings bank account. NGO will also fulfill the role of a credit intermediary. Banks would provide adequate training to NGO personnel and then provide credit to the NGOs to be given to the target rural customers. An association with NGO will have multiple benefits for the bank. Most importantly a NGO would be useful in bridging the information gap and access barrier. Both NGOs and the Bank would be involved in deciding the credit rating of a SHG for a loan. Once the loan is given, NGO would also be involved in monitoring the efficient use and deployment of the loan. Rural customer would repay the loan to the NGO that would pass it to the Bank. It is also important at this juncture to understand the reasons behind the success of an SHG model. Below we list some of the facts.

- Emphasis on Group formation and nurturing

- Members' own stake in the group in the form of savings

- Members learn to maintain financial discipline

- Collective wisdom in credit decisions

- Peer support - minimize the risks of failures

- Cost effective, operationally simple and low risk strategy for expanding client base

- $\quad$ More than $95 \%$ on-time repayment 


\section{Conclusion}

Vast segments of population, particularly the underprivileged, are yet to be brought on to the canvas of banking services. This presents the banking sector with a huge market opportunity to be tapped. With the necessary backing from RBI and its policy guidelines, banks will have to use innovative models and greater use of advanced technology to bring this critical section under the umbrella of banking services. It will ultimately lead to a greater financial inclusion and overall growth of the economy and the country.

Self Help groups, NGOs and rural supermarkets like ITC Choupal are critical elements of the four models proposed in the paper and will require a co-ordinated approach for success. The Agricultural Lending model described in the paper specifically presents how a co-ordinated approach can on one side ensure credit facilities to the farmers and also on the other side insure them against weather related losses which is huge issue in India.

Withdrawal facilities through biometric ATM's in vernacular languages, low denomination notes from the ATMs, further simplification of the KYC norms and using the postal services reach in the country are some of the other key points observed in the paper for financial inclusion.

Government through RBI should act as the change agent driving this co-ordination and defining policies to facilitate this growth. Transparency again will be the key for this approach which will not only bring credibility but also confidence among the various stakeholders.

With around 51.4\% of the farmer households still financially excluded according to ASSOCHAM, this is a huge untapped opportunity for the banks both in terms of business prospects and also in terms of overall economic growth.

\section{References}

[1] Minakshi Ramji (2009) - Working Paper Series 26, Institute of Financial Management and Research, Center for Micro finance. ifmr.ac.in/.../26_Ramji_Financial\%20Inclusion\%20in\%20Gulbarga.pdf

[2] Amol Agarwal (2008) IDBI- The need for Financial Inclusion from an Indian Perspective. Retrieved from http://www.oecd.org/dataoecd/16/55/40339652.pdf

[3] Mandira Sarma/Jesin Pais (2009) - Financial Inclusion and Development- A cross-country analysis. Retrieved from http://www.icrier.org/pdf/Mandira\%20Sarma-Paper.pdf

[4] Jasbir Singh and Ruchika Gahalot (2016) - Principles of Indian Banking, Laxmi Publications Pvt. Ltd.. India. Print

[5] Satya R. Chakravarty and Rupayan Pal (2010) - Measuring Financial Inclusion: An Axiomatic Approach, Indira Gandhi Institute of Development Research. Retrieved from http://www.igidr.ac.in/pdf/publication/WP-2010-003.pdf

[6] DF Discussion Paper (2009) How can technology facilitate Financial Inclusion in India. Retrieved from http://www.idfresearch.org/Financial-Inclusion-0901.pdf

[7]. Savita Shankar (2006) Transaction Costs in Group Micro Credit in India- Institute of Financial Management and Research

[8]. CGAP. 1995. Micro and Small Enterprise Finance: Guiding principles for selecting and supporting intermediaries. CGAP.

[9]. Seibel, H.D., and Dave, H.R. (2002) Commercial Aspects of SHG-Bank linkage programme in India, NABARD, Mumbai

[10]. H. R Machiraju (2015) Indian Financial System, Vikas Publishing, India. Print. 